\title{
Open education courses as a relevant environment for improving professional competencies of teachers
}

\author{
Cursos de educação aberta como ambiente relevante para o \\ aprimoramento das competências profissionais dos professores
}

\section{Los cursos de educación abierta como entorno relevante para mejorar las competencias profesionales de los docentes}

\author{
Elena Markovna Dzyuba ${ }^{1}$ (D), Victoria Trofimovna Zakharova ${ }^{1}$ (D), \\ Anna Leonidovna Latukhina ${ }^{1}$ (D) Tatyana Nikolaevna Sheveleva ${ }^{1}$
}

${ }^{1}$ Nizhny Novgorod State Pedagogical University, Nizhny Novgorod, Russian Federation.

Corresponding author:

Elena Markovna Dzyuba

Email: dsjubannjov@list.ru

How to cite: Dzyuba, E. M., Zakharova, V. T., Latukhina, A. L., \& Sheveleva, T. N. (2021). Open education courses as a relevant environment for improving professional competencies of teachers. Revista Tempos e Espaços em Educação, 14(33), e16164. http://dx.doi.org/10.20952/revtee.v14i33.16164

\begin{abstract}
The authors explore the problem of developing an open education course "In search of the national Russian code: educational routes" in this article. The modern approaches to the organization of lifelong postgraduate education are associated with distance technologies. The MOOC development technology for the RFL teachers is described in the article: disciplines of six modules have been formed, aimed at improving the methodological, linguocultural, linguistic, and professional communicative competencies, based on the study of the results of the questionnaire survey of future students of the courses, as well as the decomposition of professional competence. The results of this study can be used in developing an educational environment for advanced training courses.
\end{abstract}

Keywords: MOOC. Distance technologies. Russian as a foreign language. Advanced training. Professional competencies.

\section{RESUMO}

Os autores exploram o problema de desenvolver um curso de educação aberta "Em busca do código nacional russo: percursos educacionais" neste artigo. As abordagens modernas para a organização da educação de pós-graduação ao longo da vida estão associadas às tecnologias à distância. $A$ tecnologia de desenvolvimento de MOOC para os professores RFL é descrita no artigo: disciplinas de seis módulos foram formadas, destinadas a melhorar as competências metodológicas, 
linguísticas, linguísticas e comunicativas profissionais, com base no estudo dos resultados do inquérito por questionário de futuro alunos dos cursos, bem como a decomposição da competência profissional. Os resultados deste estudo podem ser utilizados no desenvolvimento de um ambiente educacional para cursos de formação avançada.

Palavras-chave: MOOC. Tecnologias à distância. Russo como língua estrangeira. Treinamento avançado. Competências profissionais.

\section{RESUMEN}

Los autores exploran el problema de desarrollar un curso de educación abierta "En busca del código nacional ruso: rutas educativas" en este artículo. Los enfoques modernos de la organización de la educación de posgrado a lo largo de la vida están asociados con las tecnologías a distancia. La tecnología de desarrollo MOOC para los profesores de RFL se describe en el artículo: se han formado disciplinas de seis módulos, orientadas a mejorar las competencias metodológicas, lingüísticas, lingüísticas y comunicativas profesionales, a partir del estudio de los resultados del cuestionario encuesta de futuro. estudiantes de los cursos, así como la descomposición de la competencia profesional.Los resultados de este estudio se pueden utilizar en el desarrollo de un entorno educativo para cursos de formación avanzada.

Palabras clave: MOOC. Tecnologías a distancia. Ruso como lengua extranjera. Entrenamiento avanzado. Competencias profesionales.

\section{INTRODUCTION}

\section{Problem statement}

Open education courses have been intensively developing in the field of higher education in recent years as a technologically equipped system for organizing the educational process, which allows the student to determine the main vectors of professional development, select an individual educational route and independently master the required research and didactic materials of the academic discipline. This format does not exclude classical forms of education in higher educational institutions (lectures, practice, workshop, colloquium), but allows to expand the horizons of the educational process and to reveal the potential of pedagogical activity and new opportunities in the professional training of a student. In a broad sense, the possibilities of open education are seen by researchers as an educational technology aimed at reaching educational objectives of a new order by the teacher and students in terms of choosing the program, teacher, place and time of study, independent planning, and "purposeful, controlled independent work" (Azimov \& Shchukin, 2009, p. 181; Polat, 2020, p. 29).

This objective for the teacher corresponds to the idea of self-realization, which is not always possible in the context of the established format of the curriculum. The technological capabilities of open education courses (MOOC) allow, for example, to develop elective courses by filling content with relevant issues that can accordingly shape the research interests of the student. Entering the space of open education technology for a teacher is also an efficient way to improve professional competencies in the subject area.

Mobile professional training or retraining is one of the trends in the modern concept of education in Russian for an RFL teacher. The issue of the mobile possibility for improving competencies in professional life is especially important for teachers from the CIS member states, where teaching in Russian has been preserved and is actively developing. Open education courses, which are primarily aimed at overcoming space-time boundaries and forming an individual educational trajectory, play an important role in supporting the professional activities of a teacher outside the Russian Federation.

2. Justification of relevance. The open education course "In search of the national Russian code: educational routes" is focused on mobility, selection of an individual educational trajectory, 
and expansion of intercultural and interethnic dialogue in the context of the intersection of professional interests of the scientific and pedagogical community in the CIS member states.

The relevance of this project is based on the data obtained as a result of the questionnaire about the demand for this type of project among the RFL teachers from Kazakhstan, Uzbekistan, Moldova, and Belarus. The course "In search of the national Russian code: educational routes" provides operational methodological support and advice in the field of mastering and studying Russian culture, literature, and language in educational institutions of the CIS.

The project allows to work with a fairly large community of teachers simultaneously, because it includes 100 options for various microcourses, the structure and specifics of which will be presented below.

The relevance of the project is determined by the orientation of the materials towards improving the sociocultural and linguocultural competencies of the RFL teacher, which creates conditions for efficient training of the teacher for teaching not only RFL, but also philological disciplines read in Russian (regional studies of Russia, linguistic and cultural studies, historical and literary courses), as well as to conduct extracurricular work with students.

In this regard, the project is focused both on the request in the Commonwealth countries and on the legislative base of the Russian Federation:

- Federal Law "On Education in the Russian Federation" No. 273-FZ dated December 29, 2012;

- concept of state support and promotion of the Russian language abroad (approved by the President of the Russian Federation No. Pr-2283 dated November 3, 2015); and

- main provisions of the Federal Target Program "Russian Language" for 2016 - 2020.

3. Novelty and significance of the study. The novelty and significance of the study are determined by the need to analyze open education courses as a relevant mobile platform that meets the modern needs in the improvement of professional competencies of RFL teachers, as well as by testing the modular model of the course, which allows using the principle of variability in the content of sections while maintaining the basic target settings associated with the RFL teaching technology, topical issues in the field of philological disciplines read in Russian, and the regional component in training and support of the teacher.

\section{LITERATURE REVIEW}

The need for lifelong development and improvement of professional competencies, expressed in the concept of lifelong learning (education throughout life), has been the subject of close attention in scientific research in recent years (Holford et al., 2020; Jarvis, 2020). The sphere of concepts of lifelong learning was analyzed (Kolesnikova, 2016), and its structure and stages in the field of professional training of a teacher were comprehended, including the "stage of professional development", "additional pedagogical education - advanced training - improvement of professional knowledge, skills, and abilities, professional and personal significant qualities" (Ippolitova, 2018, p. 7).

The idea of lifelong professional development of a teacher is analyzed in relation to the concept of postgraduate support as part of the model of targeted training of a teacher, which, according to the researchers, should be "one of the constituent elements of the regional sociopedagogical cluster" and correspond to the program of modernization of teacher education and the emerging national system for the teacher growth by the Ministry of Education and Science of the Russian Federation (Ilaltdinova et al., 2017).

The issue of improving the professional competencies of RFL teachers in their activities has been repeatedly raised in scientific research. The actual professional competencies of RFL teachers (Kryuchkova, 2013; Shibko, 2007; Latukhina \& Marinina, 2020; Dzyuba et al., 2020; Ananina \& Kuznetsova, 2015; Krasnyuk \& Yarkova, 2016) and the forms of organizing advanced training 
(Balykhina, 2006; Balykhina et al., 2003), including distance learning (Volov et al., 2000; Pronina, 2012), were the aspects of the analysis.

The traditional advanced training courses are being replaced by more diverse forms of professional development: trainings, workshop classes, and distance courses (Azimov, 2014; Vladimirova, 2017).

Open education courses (MOOC), based on distance learning, hold a special place in the modern professional training, and the attitude towards them has evolved in a fairly short time (Zakharova \& Tanasenko, 2019). Two approaches have been outlined in the use of open education courses: the ones intended for the implementation of new educational programs in universities and online courses for advanced training of graduates (Lebedeva, 2015). In both cases, the researchers highlight the principles inherent in all distance education: openness, flexibility, mobility, customization, and modularity (Volov et al.; 2000).

An attempt to model a universal online course is observed in the research. Traditionally, it includes lectures, including video/audio lectures, accompanied by teaching aids (presentations, diagrams, tables); self-instructional assignments with specific deadlines, where students in the courses can complete the assignments at a time convenient for them; forums and chat rooms for feedback; and final test (in the form of test check, project work, essays, etc.) (Lebedeva, 2015). The researchers distinguish a special type associated with the mutual review of the works performed by the participants among the assignments addressed to the course participants. This technique is aimed at the implementation of productive valuation activities.

Practice of creating a relevant environment for an RFL teacher. The open education course (MOOC) seems to be the most efficient form of implementing tasks in the field of improving professional competencies. This format allows to create a relevant professional environment, both for the RFL teacher in higher education and for teachers working in a foreign cultural educational space. The course "In search of the national cultural code: educational routes", created at the Minin University for representatives of the teaching community of the CIS member states, allows for the mobile implementation of a retraining program in RFL and philological disciplines read in Russian. Focused on self-instructional work and free planning of the teacher's employment, it assumes not only the possibility of improving the competence-based approach, but also dialogue between students and course creators in the process of mastering this program. A participant in the course can ask a question, clarify the assignment, and use the proposed materials in the further practice of teaching RFL.

The course was initially built on the basis of a survey of interested audiences in the CIS member states. The parts of the course, focused on the requests of teachers, allowed to build a model of microcourses containing parts related to the relevant aspects in the field of teaching RFL, as well as containing informative and practice-oriented materials on regional studies of Russia and axiology of the Russian culture and literature.

The request for modeling was formed on the basis of a questionnaire survey of the teaching community of Belarus, Moldova, Uzbekistan, and Kazakhstan. Metropolitan educational institutions (the Belarusian State Pedagogical University named after Maxim Tank, Minsk; the Ion Creangă State Pedagogical University in Chisinau, Chisinau; the Kazakh National Pedagogical University, Almaty; the Alisher Navoiy Tashkent State University of Uzbek Language and Literature, and the Tashkent Pedagogical University named after Nizami, Tashkent) and regional universities and schools participated in the survey. It must be noted that, for example, 14 regions of the republic teach Russian in schools in Uzbekistan alone. The following aspects turned out to be the most in demand: relevant problems of teaching RFL, including audiovisual technologies, case technology, text-centric approach to studying RFL; the method of projects and the related possibilities of developing elective courses aimed at the formation and expansion of competencies in the field of sociocultural literacy, 
as well as an in-depth approach to teaching philological disciplines among future philologistsRussianists.

The survey included 169 higher school teachers and 627 teachers teaching RFL and disciplines in Russian, a total of 796 people.

\section{METHODS}

\section{a. General description}

The authors proposed a survey in order to identify the needs of the professional community of RFL teachers in advanced training courses, which included 796 teachers of RFL from higher education and secondary schools of Kazakhstan, Uzbekistan, Moldova, and Belarus.

The most pressing problems associated with teaching RFL were identified, and the main directions of the MOOC courses were formed in the course of the survey. Most respondents saw open education courses as an opportunity to systematize and deepen knowledge (383 people), learn new pedagogical ideas and technologies (134 people), and prepare for work in the context of updating the educational content (125 people) (Figure 1 ).

Figure 1. Diagram representing the responses to the question about the possibilities of open education courses in the professional development of RFL teachers
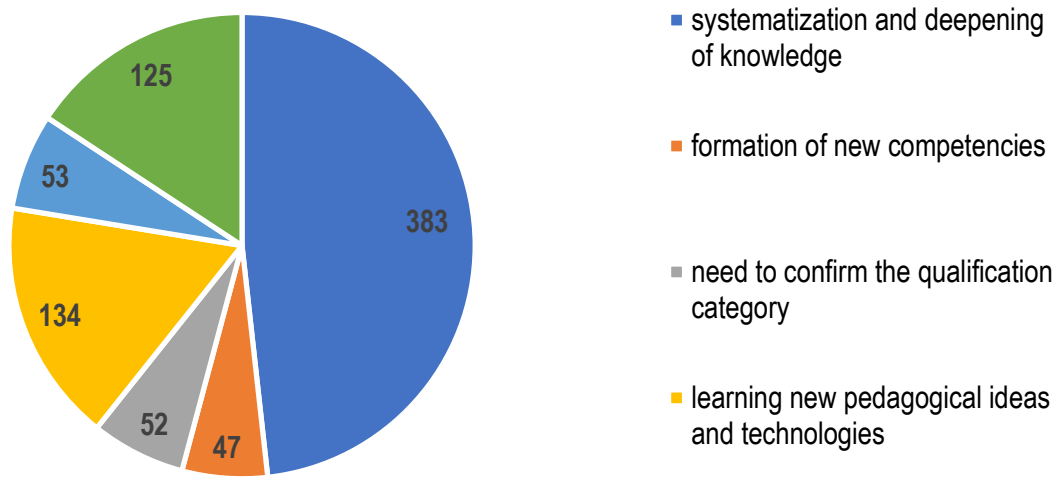

As a result of the survey on the degree of demand for course modules, the greatest interest was shown by the respondents in educational disciplines related to relevant issues of teaching RFL (286 people), developing elective courses in the practice of teaching RFL (131 people), and regional studies of Russia (126 people). The results of the survey are presented on the diagram (Figure 2 ). 
Figure 2. Diagram of the results of the survey about the demand for MOOC modules by RFL teachers

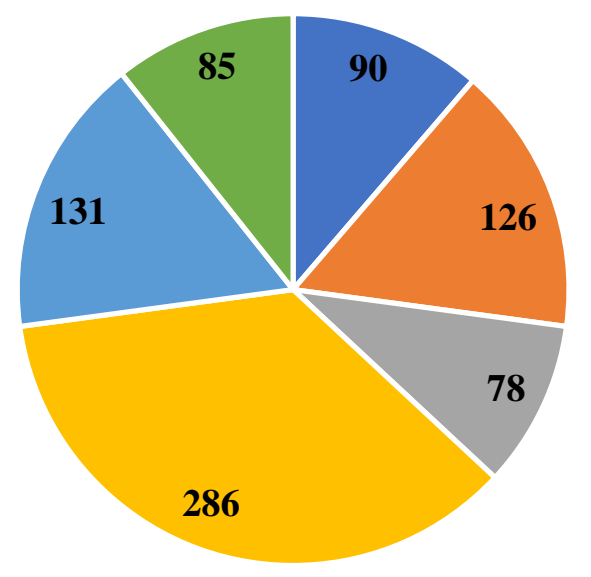

- "Value potential of Russian literature"

- "Regional studies of Russia"

- "Dialogue of cultures: problem of selfidentification from history to the present"

- "Relevant problems of teaching RFL"

- "Developing elective courses in the practice of teaching RFL"

- "Man and the world in the mirror of the Russian word"

As such, the course structure was based on two key aspects: decomposition of the professional competence of an RFL teacher and the relevant areas of professional training identified during the survey.

As a result, the professional competence of an RFL teacher was represented by the following components:

$\checkmark$ methodological competence,

$\checkmark$ linguistic competence,

$\checkmark$ linguocultural competence, and

$\checkmark$ professional and communicative competence.

The modules filled with disciplines of the students' choice were assigned for each competence (Figure 3). It was decided to increase the number of modules to two in the areas of the modern methods of teaching RFL and the issues of linguocultural orientation, due to the special interest of the course participants in these problems. 
Figure 3. Model of open education courses for RFL teachers from universities and schools

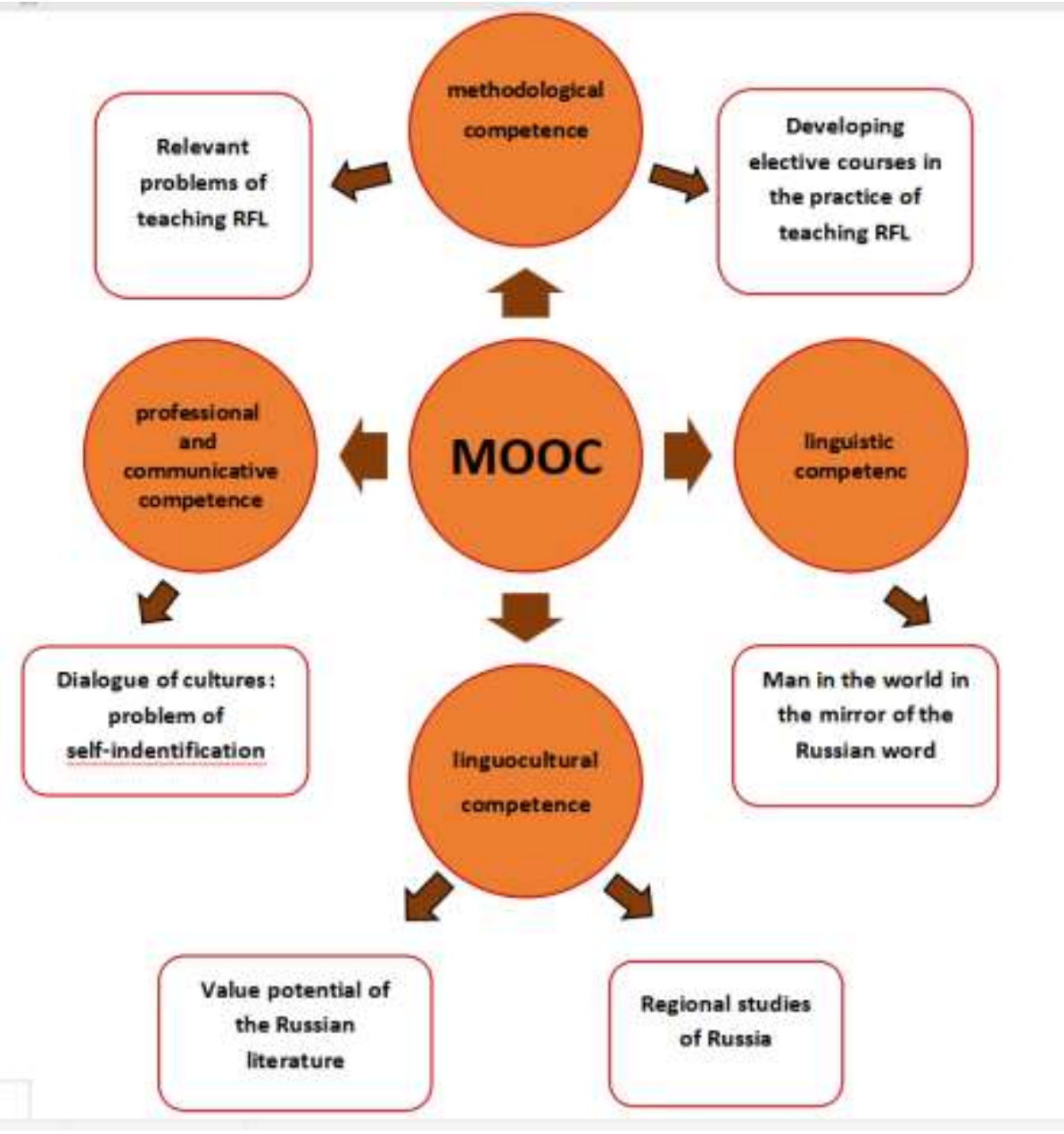

Each module included three to five disciplines, one of which was chosen by the student in accordance with the individual educational trajectory. A list of disciplines for each module is provided in Table 1.

Table 1. List of Disciplines for each module

\begin{tabular}{|c|c|}
\hline Module & Discipline \\
\hline \multirow{5}{*}{ Relevant problems of teaching RFL } & Audiovisual technologies in teaching RFL \\
\hline & Interactive technologies in teaching RFL \\
\hline & Philological analysis of the text for nonnative speakers \\
\hline & Distance teaching of RFL in the modern conditions \\
\hline & Teaching types of reading in RFL classes \\
\hline \multirow[t]{3}{*}{$\begin{array}{l}\text { Developing elective courses in the practice of } \\
\text { teaching RFL }\end{array}$} & $\begin{array}{l}\text { Developing elective courses for students of RFL at the } \\
\text { elementary level }\end{array}$ \\
\hline & $\begin{array}{l}\text { Professional orientation of an elective course at an advanced } \\
\text { stage of studying RFL: development specifics }\end{array}$ \\
\hline & $\begin{array}{l}\text { Formation of sociocultural competence in teaching RFL } \\
\text { (based on elective courses) }\end{array}$ \\
\hline \multirow[t]{2}{*}{ Value potential of the Russian literature } & $\begin{array}{l}\text { Russian literature and culture in the context of Slavic culture } \\
\text { Contemporary literary process in Russia }\end{array}$ \\
\hline & $\begin{array}{l}\text { Persons: the year of I. A. Bunin in Russia (how to read and } \\
\text { understand the writer's works) }\end{array}$ \\
\hline \multirow[t]{3}{*}{ Regional studies of Russia } & Traditional and new in Russian culture \\
\hline & Topoi of Russian culture (literary world of a noble estate) \\
\hline & Sensory perception of the verbal image in texts about Russia \\
\hline \multirow{2}{*}{$\begin{array}{l}\text { Dialogue of cultures: problem of self-identification } \\
\text { from history to the present }\end{array}$} & Name Russia: to the problem of self-identification \\
\hline & \\
\hline
\end{tabular}


Man and the world in the mirror of the Russian word
Intercultural interpretation of literary text

History of the Russian language in a functional aspect (9th 21st centuries)

Sphere of concepts of Russian culture

Language of the modern media in Russia

Business Russian language

Project activities in the Russian classes (practice)

The authors consider the subject component of the module "Relevant problems of teaching RFL" in more detail, as it was most demanded, according to the results of the survey. One of the disciplines from the module is included in each training course. For example, the course "Modern technologies in teaching RFL" contains the discipline "Audiovisual technologies in teaching RFL". Each discipline is built according to a certain layout: a lecture, questions for self-control (Figure 4), and practice.

Figure 4. Screenshot of the course page in the MOOC

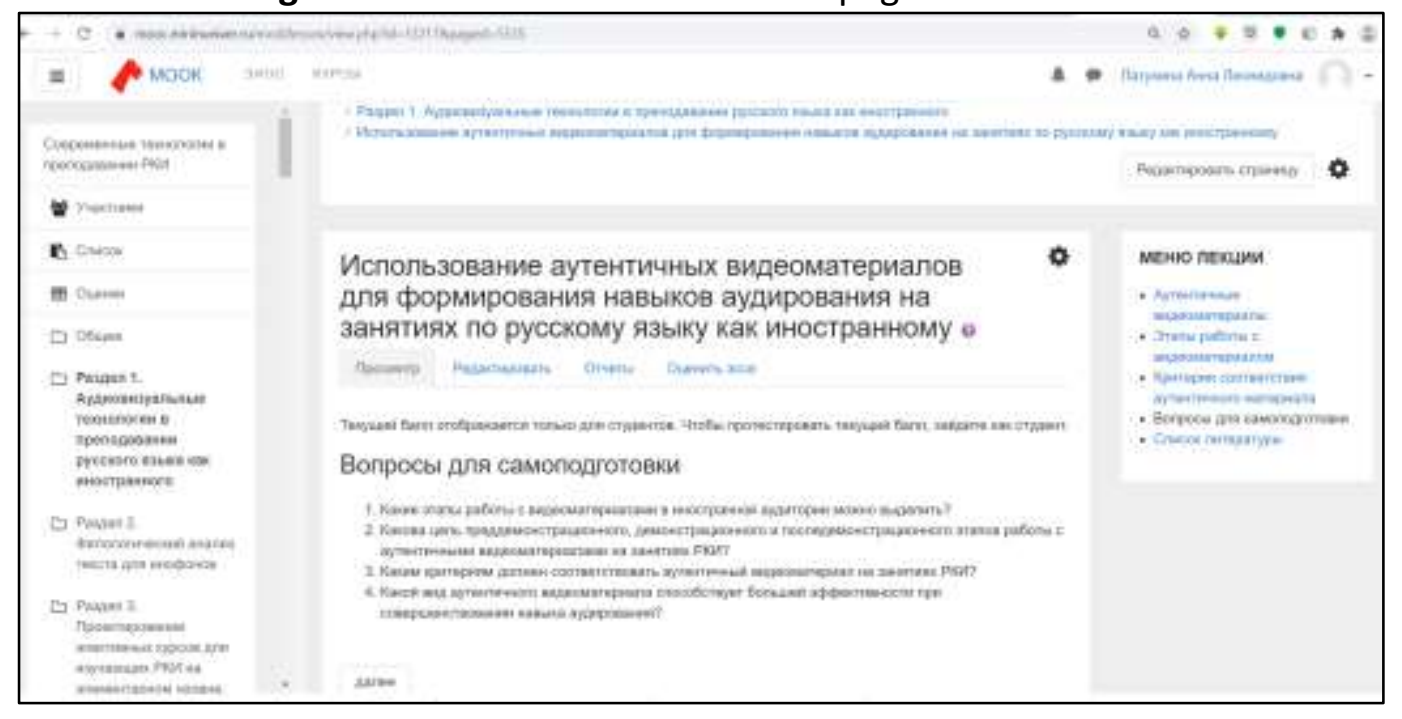

Practice involves acquaintance with fragments of lessons for students with different levels of the Russian language proficiency using authentic audiovisual video materials. Methodological developments emphasize the communicative, linguistic, and regional orientation of work with audio and video texts, at the same time demonstrating the possibilities of developing skills and abilities of all types of speech activity.

Authentic video materials allow to solve a number of educational tasks the teacher is facing at the lesson in the process of teaching listening in Russian: informational (acquaintance with the national and cultural specifics of the Russian people and the picture of the world), motivational (motivation of students for joint cognitive activity and encouragement for further self-instructional work), modeling (modeling of situations that imitate the conditions of natural communication), integrative (use of all types of speech activity: listening, speaking, reading, and writing), illustrative (visual demonstration of the realities of the life of Russian people and the specifics of their verbal and nonverbal communication), developing (development of attention and mechanisms of memory, thinking, etc., broadening the horizons and increasing the level of the general culture of students), and educational (mastering the skills of intercultural communication).

The main goal of intercultural foreign language education is the development of a personality capable of communicating and socially interacting in the target language. Regional and sociocultural information contained in the modern RFL textbooks is not enough to conduct intercultural dialogue. The study of the language and its culture through the prism of one's native culture can be facilitated by the increasingly relevant case technology, which, unlike the tasks 
forming sociocultural competence, does not contain clear instructions - instead, the principle of cultural relativism is applied. The popularity of interactive technologies, including case studies, is determined by the fact that they help increase interest in the subject of study and motivation of students, activate mental activity through the creation of a communication situation, and generally allow to optimize the learning process and improve its quality. That is why this technology was chosen in a number of courses in the study of interactive technologies (Figure 5).

Figure 5. Screenshot of the MOOC practice

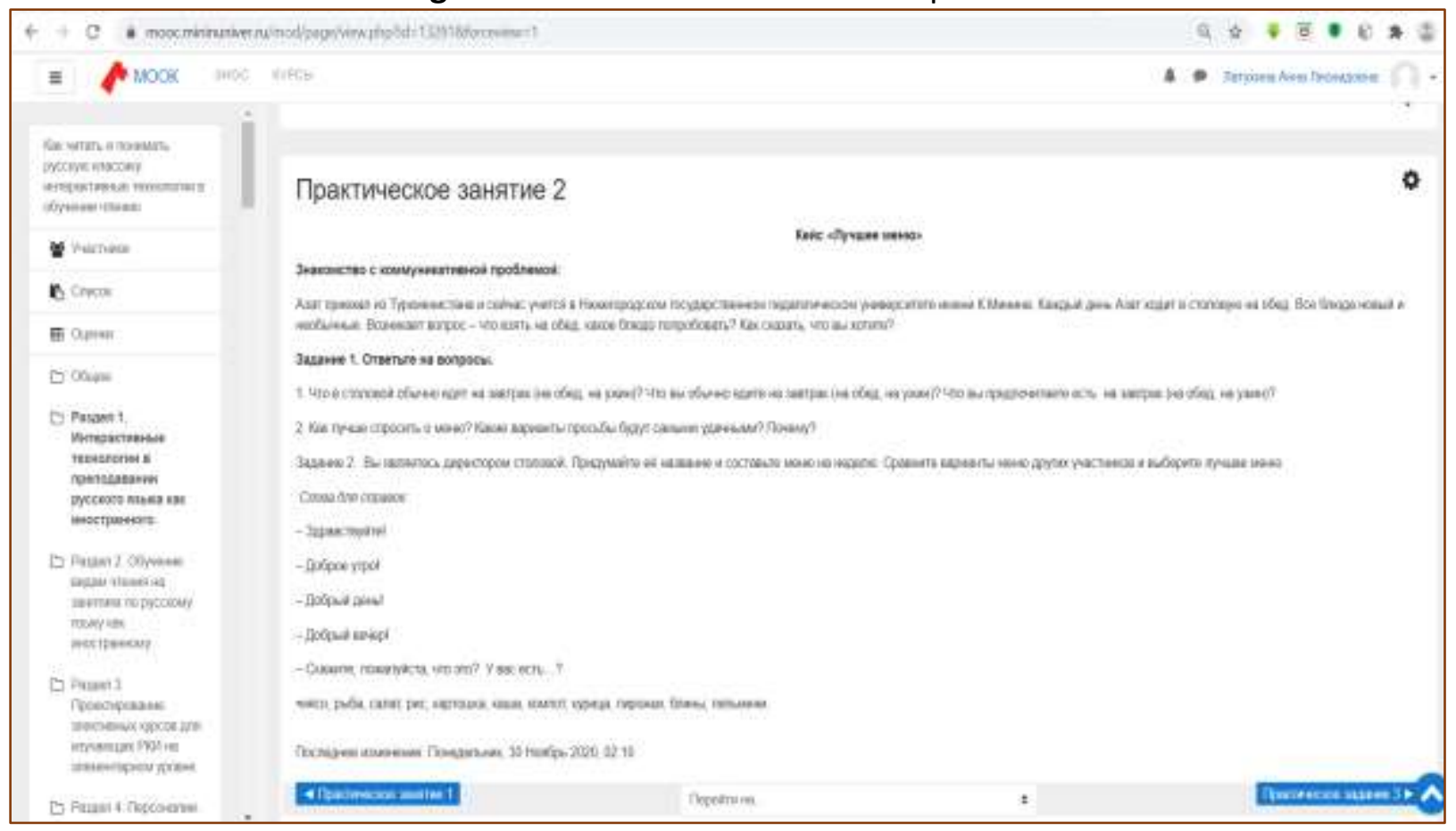

Literary texts are of great interest to teachers in terms of their use in the RFL practice. Literary texts of Russian classics and works of the modern Russian literature solve various educational problems: from purely linguistic to the world outlook. An important issue for a teacher in a foreign audience is such a formulation of the question, where the ability to generalize the received information, understanding the subtext, finding the connections between the semantic fragments of the work, and, finally, the ability to perceive the text in a wide social and cultural context are formed. In this regard, the modules provide a variety of methods for working with literary text. "Philological analysis of the text in teaching RFL" is one of the disciplines of the module under consideration (Figure 6).

Figure 6. Screenshot of the course sections page

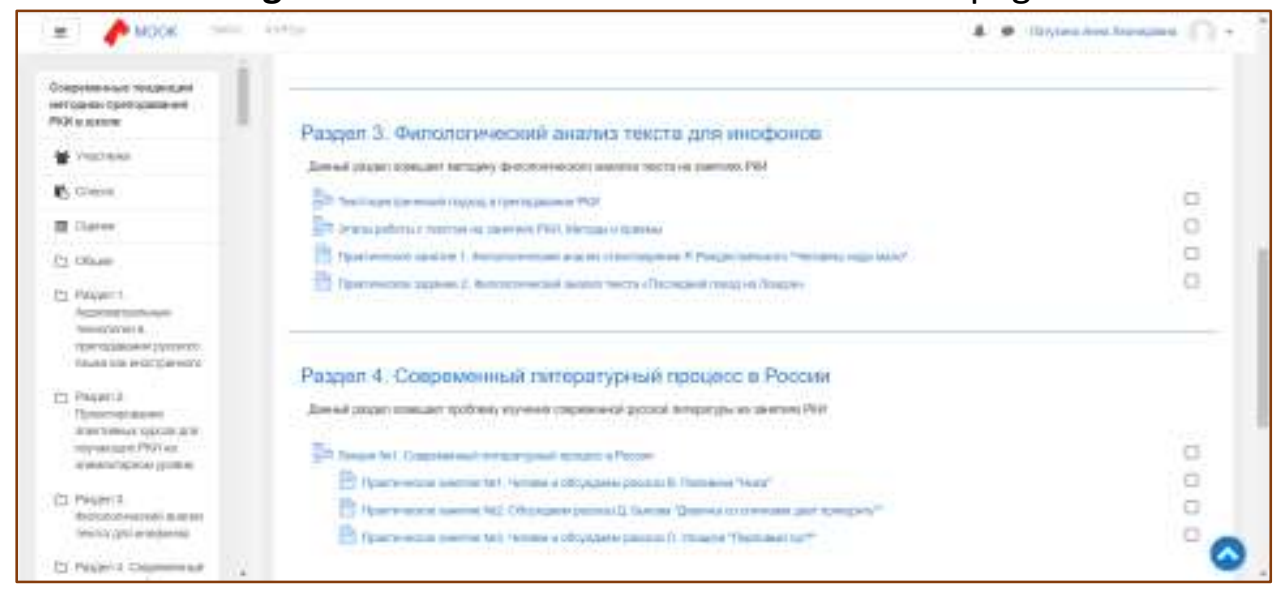


As evidenced in practice, a comprehensive philological analysis of the text involves the interaction between literary and linguistic approaches. In this regard, a literary text is viewed as an aesthetic phenomenon with integrity, imagery, and functionality; as a form of addressing the world, i.e., as a communicative unit, where, in turn, a certain communicative situation is modeled; and as a particular dynamic system of linguistic means (Baryshnikova \& Shtyrina, 2013).

Teaching reading as a type of speech activity is one of the goals of teaching the Russian language among nonnative speakers, while the main problem is the formation of the ability to read correctly, depending on the communicative attitude, which can be modified and refined as the information is understood. Communicative attitudes can be of different nature and goals: search, viewing, study, or introductory reading. According to the requirements of the RFL standard, the skills associated with reading technique are formed at the initial stage together with the development of the phonetic course of the Russian language (Figure 7).

Figure 7. Screenshot of a lecture fragment

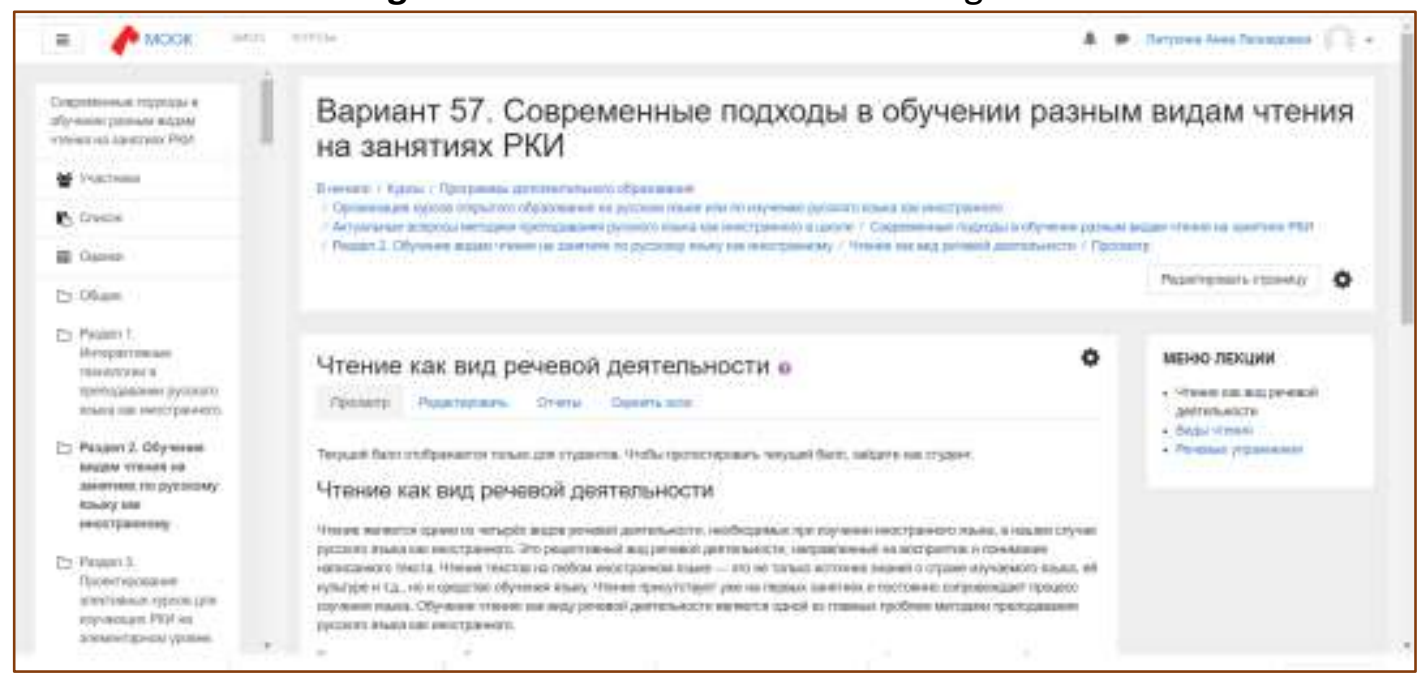

The issues of distance teaching RFL are becoming central in the assessment of the current situation in education. It is believed that distance learning has some specifics, such as mobility, individual trajectory, and independence. The increased attention to the problem of distance education is associated with the difficulties experienced by foreign students: low internal motivation, weak self-organization, adaptation to new technologies, but most importantly, the lack of live contact with the teacher (Figure 8). 
Figure 8. Screenshot of the course page with practice

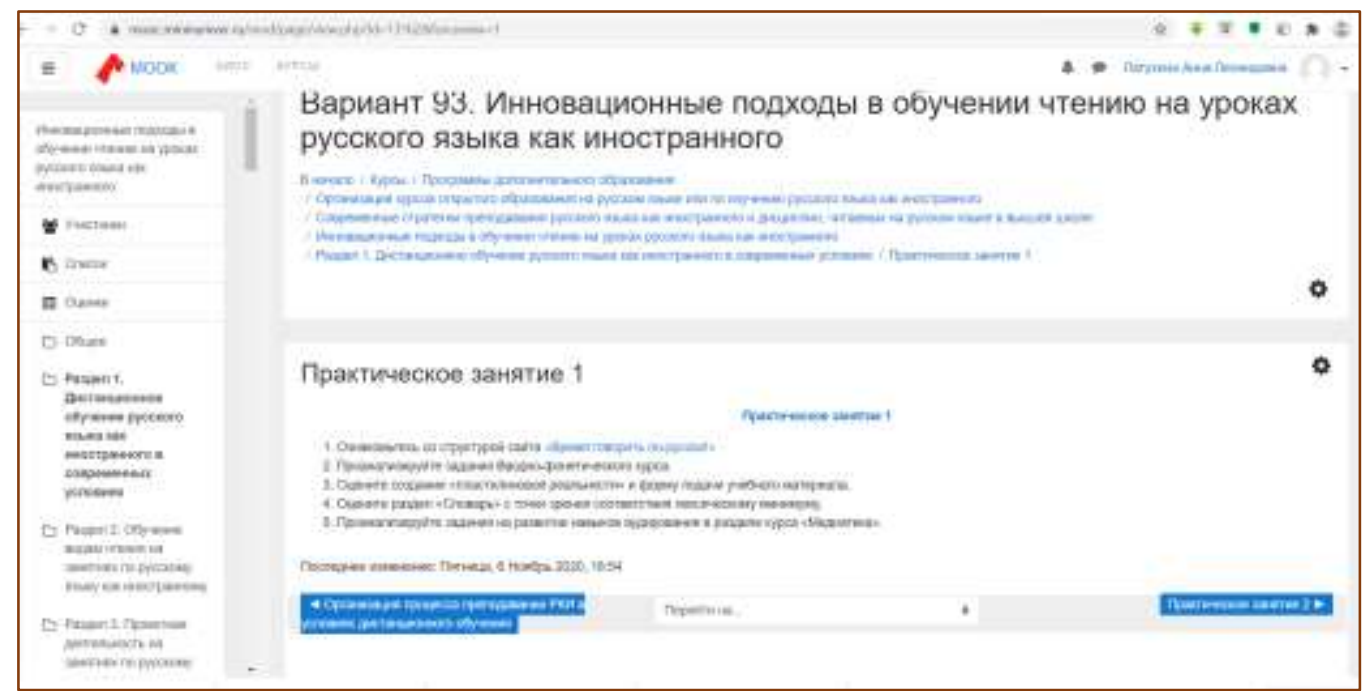

The digital transformation of education has become a reality, and new challenges put forward new approaches to their solution. As a result, the need arises to study the possibilities of teaching online on various platforms and to develop a set of tasks for a foreign audience that are adequate to the new realities. Assessing the state of distance learning today, leading RFL teachers note the insufficient development of online lessons and the introduction of distance technologies into the practice of teaching languages (Azimov, 2020). In this regard, the role of the teacher and their level of preparedness to conduct lessons online is increasing, and the issue of information literacy and lifelong professional development in the field of digitalization of education becomes more relevant than ever. The analysis of the current situation allows to draw conclusions that the practice of education among nonnative speakers is largely rethought, and the mechanisms of adaptation to the new conditions of the educational environment are gradually turning on.

The professional training of an RFL teacher, as well as of a teacher of the Russian language and literature in a foreign cultural environment cannot be limited to the linguistic disciplines only. The linguocultural approach, which has become the future base for the study of foreign languages, when included in the educational process of an RFL teacher or a Russian philologist of variable philological disciplines, significantly "reconfigures" the competence model of a specialist. This reconfiguration results in the ability to navigate in the cultural and regional problems of the country of the target language, actualization of important semantic (conceptual) fields, as well as the construction of dialogical relations in a foreign cultural space, work with a verbal image in the field of a literary text, and the formation of metaphorical competence. The introduction of the modules "Value potential of the Russian literature", "Regional studies of Russia", and "Dialogue of cultures: problem of self-identification from history to the present" into the modular open education course for RFL teachers should correct the professional motivation of students by identifying new opportunities and ways of developing the competencies of an RFL teacher.

The need for such an approach to the formation of the content of the open course and the choice of the problems of modules is partly confirmed by the data from the questionnaire. As follows from the "Diagram of the results of the survey about the demand for MOOC modules by RFL teachers" (Figure 2), in percentage terms, the initial choice in favor of regional studies, the "Regional studies of Russia" module ( $86 \%$ of the respondents), competes with the modules of philological and/or historical literary orientation, "Value potential of the Russian literature" (50\%) and "Dialogue of cultures: problem of self-identification from history to the present" (45\%). However, drawing up an individual educational route as one of the basic principles of forming study groups in an open course allows to offer alternative opportunities for mastering the competence potential of an RFL 
teacher, even as part of the well-known (familiar) disciplines. For example, the module "Regional studies of Russia" included the discipline "Sensory perception of the verbal image in texts about Russia", which allowed to actualize modern linguopoetic and linguosensory studies in relation to the problems of teaching RFL (Dzyuba \& Latukhina, 2020).

The course "In search of the national Russian code: educational routes" is developed with due consideration of the understanding by the students of key word images representing the specifics of the Russian mentality, which are indicated in the texts of the literary ambassadors of Russia (discipline "Persons: the year of I. A. Bunin in Russia (how to read and understand the writer's works"). In general, the model "Value potential of the Russian literature" presents the Russian literature as part of the Slavic world, makes the problem of developing the modern literary process relevant, within which new meanings of the development of the sociocultural space of Russia are formed, and also allows the introduction of regional materials, the so-called "Nizhny Novgorod text of the Russian literature", which participate in the formation of the national Russian code in the focus of one cultural phenomenon (Zakharova, 2020; Sheveleva, 2020).

\section{RESULTS}

As a result of processing the data of the survey on the demand for open education courses, in particular in order to improve the professional competencies of an RFL teacher, a modular system of the course "In search of the national Russian code: educational routes" was formed, which allowed to create individual educational routes configured in 100 options, developed for the mobile implementation of a professional request in groups of higher education teachers and school teachers teaching RFL. Each of the options includes five sections. Section $\mathbf{1}$ and Section $\mathbf{2}$ present relevant problems of the theory and technology of teaching RFL (for example, audiovisual technologies in teaching Russian as a foreign language and philological analysis of text for nonnative speakers). Section 3, as a rule, is dedicated to the method of project activities of an RFL teacher. Section 4 offers options for mastering and analyzing authentic texts saturated with verbal images representing the national code (city of Kitezh, Volga, "Russian Nile" noble estate, topoi of Russia in the work of individual authors representing the image of Russia in their works: A. Pushkin, I. A. Bunin, V. V. Rozanov, and others). Section 5 contains the "Final test".

The individualization of the educational route, which became the conceptual basis of the project and the course itself, allowed to ensure the universality principle of the offer of the advanced training program and at the same time to focus on the diversity in demand for an educational program for improving professional competencies.

As a result, the conditions have been created for:

- the formation, development, and improvement of competencies in the field of technologies, methods, and techniques of the linguocultural and communicative activity approach in teaching RFL;

- the development of professional competencies in the creation of work programs for disciplines, including elective courses in the disciplines of the philological cycle;

- the improvement of the understanding of the national cultural code based on concepts and verbal and artistic images that form the idea of the Russian world and intercultural dialogue; and

- the creation of conditions for high motivation for learning and involvement in the educational process due to the variability of the modules, which allows to unlock the individual abilities and creative potential of students.

Finally, it is also obvious that teachers overestimate their ideas about information culture and work in a distributed information environment, when finding themselves in the role of a student in the current professional environment of an open course. 


\title{
CONCLUSION
}

\section{Application and suggestions for further research}

The results of this research can be used in further pedagogical activities in developing the educational environment for advanced training courses for teachers of higher education and RFL teachers in the practice of teaching disciplines for students in the magistracy in the profile "Teaching RFL".

The development and planning of courses for advanced training in the field of teaching philological disciplines can become a prospect for research activities.

\begin{abstract}
Authors' Contributions: Elena Markovna Dzyuba: conception and design, acquisition of data, analysis and interpretation of data, drafting the article, critical review of important intellectual content. Victoria Trofimovna Zakharova: conception and design, acquisition of data, analysis and interpretation of data, drafting the article, critical review of important intellectual content. Anna Leonidovna Latukhina: conception and design, acquisition of data, analysis and interpretation of data, drafting the article, critical review of important intellectual content. Tatyana Nikolaevna Sheveleva: conception and design, acquisition of data, analysis and interpretation of data, drafting the article, critical review of important intellectual content. All authors have read and approved the final version of the manuscript.
\end{abstract}

Ethics Approval: Not applicable.

Acknowledgments: Not applicable.

\section{REFERENCES}

Ananina, M. Yu., \& Kuznetsova, A. Ya. (2015). Metodicheskaya kompetentnost kak sostavlyayushchaya professionalnoy podgotovki prepodavatelya [Methodological competence as a component of the teacher's professional training]. Relevant problems of the humanities and natural sciences, 6-3, 10-12.

Azimov, E. G. (2014). Massovyye otkrytyye onlayn-kursy v sisteme sovremennogo obrazovaniya [Massive open online courses in the system of the modern education]. Distance and virtual learning, 12(90), 4-12.

Azimov, E. G. (2020). Elektronnyye uchebniki po russkomu yazyku kak inostrannomu: sovremennoye sostoyaniye i perspektivy razvitiya [Russian as a foreign language e-textbooks: current state and perspectives]. Rusistika, 18(1), 3953. http://dx.doi.org/10.22363/2618-8163-2020-18-1-39-53

Azimov, E. G., \& Shchukin, A.N. (2009). Otkrytoye obrazovaniye [Open education]. In: New dictionary of methodical terms and concepts (theory and practice of teaching languages). Moscow: IKAR, pp. 181-182.

Balykhina, T.M. (2006). Deyatelnost' prepodavatelya RKI kak razvivayushchaya Sistema [Work of an RFL teacher as a developing system]. In: Shchukin, A. N. (Ed.). Language and culture in a philological university. Relevant problems of study and teaching: collection of scientific works. Moscow: Filomatis, pp. 51-59.

Balykhina, T. M., Markina, T. V., \& Kharitonova, O. V. (2003). Povysheniye kvalifikatsii kak sistema nepreryvnogo formirovaniya professionalnoy kompetentsii filologa [Professional development as a system of lifelong formation of the professional competence of a philologist]. In: Russian word in a new culture: proceedings of the 10th IATRLL Congress, June 30 - July 5, 2003, St. Petersburg, Russia. St. Petersburg: Politekhnika.

Baryshnikova, E. N., \& Shtyrina, E. V. (2013). Rol i mesto predperevodcheskogo analiza khudozhestvennogo teksta v obuchenii studentov-lingvistov russkomu yazyku kak inostrannomu [Role and place of pre-translation analysis of a literary text in teaching linguistic students Russian as a foreign language]. Bulletin of the Peoples' Friendship University of Russia. Series "Russian and foreign languages and methods of teaching them", 4, 39-44.

Dzyuba, E. M., \& Latukhina, A. L. (2020). Verbalizatsiya sensoriki gorodskogo prostranstva Nizhnego Novgoroda na zanyatiyakh po RKI [Verbalization of the sensorics of the urban space of Nizhny Novgorod in the RFL classes]. In: Shaklein, V. M. (Ed.). Russian language in the modern scientific educational space: collection of abstracts of the International scientific conference dedicated to the 90th anniversary of Professor Serafima Alekseevna Khavronina, October 28-29, 2020, Moscow, Russia. Moscow: RUDN, pp. 153-155.

Dzyuba, E. M., Zakharova, V. T., Ilchenko, N. M., Latuhina, A. L., \& Sheveleva, T. N. (2020). Intellectual Resource as a Factor of Ensuring National and Cultural Security in the Conditions of the Training Course "Teacher of Russian as a Foreign Language". In: Popkova, E. \& Sergi, B. (Eds.). The 21st Century from the Positions of Modern Science: 
Intellectual, Digital and Innovative Aspects. ISC 2019. Lecture Notes in Networks and Systems, vol. 91. Cham: Springer, pp. 477-483. https://doi.org/10.1007/978-3-030-32015-7 54

Holford, J., Jarvis, P., \& Griffin, C. (2020). International Perspectives on Lifelong Learning. Routledge, 384 p.

Ilaltdinova, E. Yu., Filchenkova, I. F., \& Frolova, S. V. (2017). Osobennosti organizatsii postdiplomnogo soprovozhdeniya vypusknikov programmy tselevogo obucheniya v kontekste soprovozhdeniya zhiznennogo tsikla professii pedagoga [Peculiarities of organization of postgraduate association of alumni study training programs in the context of life cycle support of the teacher profession]. Bulletin of the Minin University, 3, 1-12.

Ippolitova, N. V. (2018). Sistema dopolnitelnogo pedagogicheskogo obrazovaniya [System of additional pedagogical education]. Bulletin of the SUSU. Series "Education. Pedagogical Sciences", 10(1), 6-12.

Jarvis, P. (2020). Learning in Later Life. An Introduction for Educators and Carers. Routledge, 178 p.

Kolesnikova, I. A. (2016). Kontseptosfera nepreryvnogo obrazovaniya: logika i metodologiya izucheniya [Sphere of concepts of lifelong education: logic and methods of study]. Lifelong education: the 21st century, 3(15), 124-140.

Krasnyuk, I. N., \& Yarkova, M. Yu. (2016). Sovershenstvovaniye professionalnoy kompetentsii prepodavatelya russkogo yazyka kak inostrannogo $v$ tselyakh povysheniya effektivnosti i kachestva obucheniya inostrannykh studentov [Improvement of the professional competence of a teacher of Russian as a foreign language with the aim of improving the efficiency and quality of teaching foreign students]. Scientific and methodological electronic journal "Concept", 43, $276-280$.

Kryuchkova, L. S. (2013). Slagayemyye professionalnoy kompetentnosti prepodavatelya RKI [Components of professional competence of a Russian as a foreign language teacher]. Multilingual and transcultural practices, 1, 1217.

Latukhina, A. L., \& Marinina, Yu. A. (2020). Professionalnyy portret prepodavatelya russkogo yazyka kak inostrannogo: kompetentnostnyy podkhod [Professional portrait of a teacher of Russian as a foreign language: competence-based approach]. Bulletin of the Minin University, 8(4), 4.

Lebedeva, M. B. (2015). Massovyye otkrytyye onlayn-kursy kak tendentsiya razvitiya obrazovaniya [Massive open online courses as a trend in the development of education]. Man and Education: Academic Bulletin of the Institute of Pedagogical Education and Adult Education, 1, 105-108.

Polat, E. S., (Ed.). (2020). Pedagogicheskiye tekhnologii distantsionnogo obucheniya [Pedagogical technologies of distance learning]: textbook for universities. 3rd ed. Moscow: Urait, $392 \mathrm{p}$.

Pronina, L. A. (2012). Otkrytoye informatsionno-obrazovatelnoye prostranstvo kak komponent sovremennogo obrazovaniya [Open information and educational space as a component of the modern education]. Gaudeamus, 2(20), 28-30.

Sheveleva, T. N. (2020). Formirovaniye sotsiokulturnoy kompetentsii pri izuchenii stranovedcheskogo materiala [Formation of sociocultural competence in regional studies] (Nizhny Novgorod text in the RFL classes). In: Shaklein, V. M. (Ed.). Russian language in the modern scientific educational space: collection of abstracts of the International scientific conference dedicated to the 90th anniversary of Professor Serafima Alekseevna Khavronina, October 28-29, 2020, Moscow, Russia. Moscow: RUDN, pp. 241-244.

Shibko, N. L. (2007). Professionalnaya kompetentsiya prepodavatelya RKI: problema opredeleniya, soderzhaniya, struktury [Professional competence of an RFL teacher: problem of definition, content, structure]. In: Potapov, I. N. (Ed.). Russian is the first language of communication in space: materials of the International research-to-practice conference, December 18-19, 2007, Vitebsk, Belarus. Vitebsk: Vitebsk State University, pp. 149-155.

Vladimirova, L. (2017). Distantsionnoye obucheniye inostrannym yazykam [Distance learning in foreign languages]. Saarbrucken: Lap Lambert Academic Publishing, 57 p.

Volov, V. T., Chetyrova, L. B., \& Volova, N. Yu. (2000). Distantsionnoye obrazovaniye: istoki, problemy, perspektivy [Distance education: origins, problems, prospects]. Samara: Samara Scientific Center RAS, p. 31.

Zakharova, V. T. (2020). Sakralnyye toposy Nizhegorodskoy zemli v literature [Sacred topoi of the Nizhny Novgorod land in literature] (in the coverage of the participants of the Seventh international scientific conference "Nizhny Novgorod text of the Russian literature as comprehension of national mentality", 2019). In: Shaklein, V. M. (Ed.). Russian language in the modern scientific educational space: collection of abstracts of the International scientific conference dedicated to the 90th anniversary of Professor Serafima Alekseevna Khavronina, October 28-29, 2020, Moscow, Russia. Moscow: RUDN, pp. 20-21. 
Zakharova, U. S., \& Tanasenko, K. I. (2019). MOOK v vysshem obrazovanii: dostoinstva i nedostatki dlya repodavateley [MOOC in higher education: pros and cons for teachers]. Education Issues, 3, 176-202.

Received: 31 May 2021 | Accepted: 09 July 2021 | Published: 31 JUly 2021

(c) (7)

This is an Open Access article distributed under the terms of the Creative Commons Attribution License, which permits unrestricted use, distribution, and reproduction in any medium, provided the original work is properly cited. 